\title{
Connessioni storiche fra il disegno e il design. Qual è la lezione della Scuola di Ulm?
}

\author{
Enrica Bistagnino
}

Abstract

Hochschule für Gestaltung, Ulm, 1950- 1968, luogo di fondazione teorica del design, scuola, momento di confronto 'spregiudicato', spazio di dialogo con l'industria, contributo alla rieducation democratica della Germania.

Con riferimento a questi e altri significati, il saggio affronta il tema del Disegno a Ulm, per approfondirne alcune questioni teoriche e procedurali, ed evidenziarne le valenze nei processi di configurazione.

Si ripropone un riferimento "classico" del design, rispetto al quale ogni rilettura è una lettura di scoperta. Le varie interpretazioni, infatti, contribuiscono a precisare l'HfG e a offrirla come modello da applicare, modificare, oppure negare.

La relazione fra il tema proposto e il 'connettere' si attua su due piani: il primo riguarda la sfera spazio-temporale, la connessione con un'esperienza teorico-didattica situata in un lontano contesto geografico e storico a cui corrisponde una distanza culturale non trascurabile; il secondo riguarda la relazione tra il disegno e il progetto. Si vuole segnalare la portata anticipatoria rispetto alla dimensione generativa della rappresentazione digitale. Si vuole mostrare un "digitale ante litteram", realizzato attraverso una dimensione scientifica e insieme artigianale.

II metodo adottato prevede la descrizione del disegno attraverso un processo top/down: a partire da alcune questioni teoriche e culturali evolve verso temi tecnico-metodologici, fino alla descrizione della prassi applicativa.

Parole chiave

disegno per il design, storia della rappresentazione, 'Hfg di Ulm', metodologia per il design, didattica della rappresentazione.

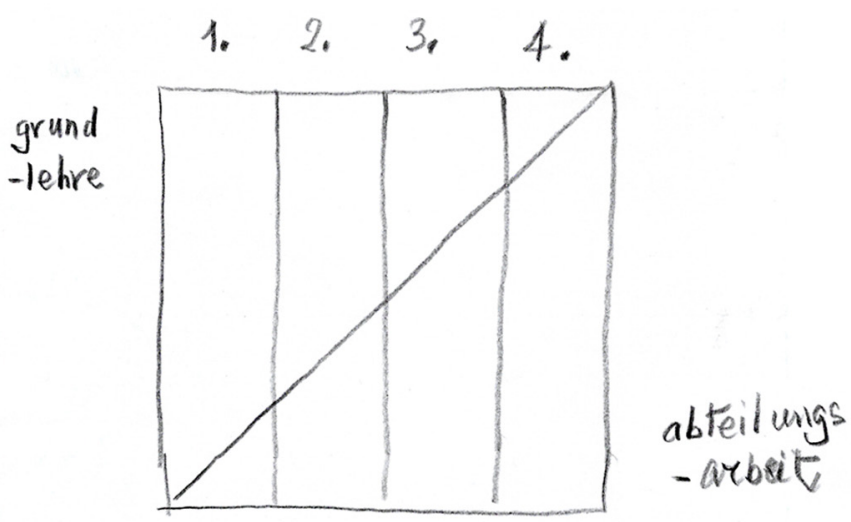




\section{Introduzione}

II Disegno all'HfG di Ulm è stato una disciplina importante.

È un pensiero che emerge da una conversazione con Tomàs Maldonado $[I]$ - colui dai più indicato come uno fra i principali protagonisti dell'HfG, fondatore teorico, ma anche pragmatico e pedagogico [2] - e ulteriormente ribadito da Giovanni Anceschi [3].

Ciò premesso, prima di descrivere il disegno all'HfG, le sue 'forme' e il suo ruolo, è necessario ricordare, seppur in sintesi, alcuni elementi costitutivi del pensiero ulmiano, in particolare quello conseguente al rinnovamento teorico introdotto da Tomàs Maldonado. Si tratta, infatti, di argomenti centrali per la definizione dei contenuti e dei metodi didattici degli insegnamenti svolti all'Hfg, compresi, ovviamente, quelli della rappresentazione.

Accennerò, quindi, ad alcuni aspetti che, da diverse prospettive, sembrano paradigmatici di una revisione culturale, radicale e complessiva, portata da Ulm al design del secondo Novecento; farò riferimento, in particolare, al processo metodologico progettuale e alla sua pedagogia, all'idea di oggetto, e alle sue valenze etiche ed estetiche.

\section{Una nuova idea di design}

La questione più significativa è senza dubbio il cambiamento di visione del design, che inizia a maturare e a essere esplicitato nella messa in discussione delle teorie e della didattica del Bauhaus (1919-1933), l'esperienza formativa, fra quelle della consolidata tradizione tedesca [4] più vicina all'HffG [5], e che consegue certamente dagli obiettivi generali della Scuola - il miglioramento della società, rispondendo a bisogni materiale e immateriali, e la reeducation democratica del popolo tedesco nello scenario drammatico del secondo dopoguerra. II venir meno dell'iniziale continuità con la Scuola di Gropius, determinato da un gruppo di giovani docenti progressisti, Otl Aicher, Hans Gugelot, Tomàs Maldonado, che ne contrastavano, sostanzialmente, la prassi soggettiva ed empirica alla base del learning by doing e la figura di designer-artista conseguente al modello formativo, è chiarito in modo definitivo dal discorso inaugurale pronunciato da Maldonado, nuovo rettore della Scuola. "II tentativo di proseguire il Bauhaus alla lettera equivarrebbe a uno sforzo di mera restaurazione, i migliori di coloro che appartennero al Bauhaus concorderanno sicuramente nel riconoscere che una prosecuzione del Bauhaus implica oggi l'essere in un certo senso contro il Bauhaus. Noi assumiamo solo il suo atteggiamento progressista, anticonvenzionale, l'aspirazione a dare un contributo alla società, nella rispettiva situazione storica. In questo senso, e solo in questo senso, noi proseguiamo il lavoro del Bauhaus" [Maldonado 1957] [6].

In relazione a questa audace attestazione di autonomia, Maldonado e gli altri docenti progressisti dichiarano che il design deve riguardare un'ampia gamma di prodotti (fra cui mezzi di trasporto, elettrodomestici, apparecchi medicali, nonché sistemi di informazione ecc.) e, quindi, deve essere l'esito di una progettualità rinnovata, basata su processi di analisi, progetto e valutazione adeguati al livello di complessità nonché alla funzione dei prodotti stessi. Da questa generale ridefinizione dell'idea di design, qui solo accennata, consegue quella revisione profonda, riferita, soprattutto, ai temi dell'etica, dell'estetica, del metodo e della scienza, che risulta pervasiva della formazione, in tutte le sue espressioni, compresa, come vedremo, quella relativa al disegno.

Secondo la nuova visione etica del design, orientata verso la progettazione sociale dell'ambiente, Ulm individua nella collaborazione di progettisti, ingegneri, scienziati, laboratori di ricerca, ambiti della produzione e del commercio, un modello fondamentale e innovativo per passare da una concezione prevalentemente formale del prodotto a una funzionale basata su una metodologia logico-deduttiva, attraverso la quali produrre, appunto, valori oggettivi.

(nella pagina precedente): Giovanni Anceschi, schema grafico del modello didatticopedagogico della Scuola di Ulm. Disegno a mano libera elaborato da Giovanni anceschi (Milano, 26 Febbraio 2018). Se il design è, quindi, design dell'interno', della struttura e del funzionamento, se la progettazione tecnica degli oggetti è centrale, allora vi saranno importanti risvolti in relazione alla questione estetica. II design così inteso risulta evidentemente estraneo alla sfera del gusto, e questo almeno per due motivi. 
In primis, per il fatto che il processo ideativo, così come pensato a Ulm, 'inibisce' processi di elaborazione della forma autonomi rispetto alla progettazione tecnico-costruttiva del prodotto stesso. Poi, perché l'aggiornamento continuo del gusto secondo criteri che non dipendono da reali necessità di perfezionamento dei prodotti, ma dal bisogno di novità principalmente motivato da logiche di mercato, genererebbe a oltranza la decadenza del gusto stesso e l'allontanamento dal perfezionamento tecnico-costruttivo dei prodotti verso cui il progetto deve tendere.

Si verrebbe a realizzare un paradosso progettuale: la pianificazione dell'usura, dell'obsolescenza, e il conseguente continuo ridisegno della forma esteriore degli oggetti.

La questione estetica, che fra l'altro accende ancora la critica nei confronti del Bauhaus -responsabile, secondo Maldonado, di aver promosso un'estetica razionalista della produzione industriale, ovvero di aver soppresso un repertorio artistico, ma di averlo sostituito con un altro pure artistico - e la forte tensione etica alimentano la ricerca orientandola verso la definizione di processi di analisi e gestione dei dati, funzionali all'elaborazione e allo sviluppo dei contenuti di progetto che è spazio di elaborazione metodologica finalizzata alla determinazione di soluzioni oggettive, 'partecipate' e verificabili [7].

Per sostenere questo approccio progettuale, la didattica si arricchisce di insegnamenti scientifici, spesso insegnati da matematici e filosofi [8], quali, a titolo di esempio: Metodologia, Analisi combinatoria, Teoria dei giochi, Teoria dell'informazione, Logica matematica, Algebra commutativa, Programmazione lineare, Teoria dei sistemi, Teoria delle code, Topologia combinatoria.

Secondo questa revisione didattica i piani di studio dell'HfG sistematizzano l'offerta formativa intorno a tre aree scientifiche - le Scienze di Base (Analisi matematica, Cibernetica, Fisica, Metodologia Teoria della scienza,Teoria della percezione, Disegno costruttivo, Scrittura, ecc.); le Scienze Sociali (Linguistica, Semiotica, Sociologia, Psicologia, Economia, Politica ecc.); le Scienze della Storia (Storia della civiltà, Storia del cinema, Storia del disegno industriale, Storia della letteratura ecc.) - integrate dalla prassi.

Allinterno di una concezione formativa che coniuga neopositivismo e pragmatismo, si attua, così, quel rapporto dialettico tra pensiero e azione che, secondo il modello di Maldonado deve prevedere una progressiva sostituzione degli insegnamenti teorici con quelli pratici (progettuali).

\section{Disegno}

Anche il disegno, come il design a cui è intrinsecamente legato, risente in modo palese della complessiva visione etica, estetica, metodologica dell'HfG.

Ciò si riscontra su diversi piani - da quello del segno grafico a quello tecnico-metodologico, a quello conformativo - e riguarda le espressioni disciplinari in senso stretto così come quelle manifestazioni che si intrecciano in modo marcato con linguaggi contigui, penso, in particolare, al disegno per la comunicazione visiva.

Che cosa è, dunque, il disegno a Ulm? Quali sono le sue declinazioni? Quali le sue connessioni con i processi elaborativi del design?

Secondo il pensiero di Tomàs Maldonado, il disegno con la $\mathrm{D}$ maiuscola, quindi un disegno "intellettuale prima che grafico", potremmo dire inteso nell'accezione albertiana di lineamenta, è la testualizzazione del linguaggio progettuale, la sua scrittura; in altri termini è la condizione del progetto, ne è forma sostanziale, in quanto luogo di costruzione ed elaborazione dell'idea.

Un'idea di disegno, riferibile al disegno euristico praticato a mano libera, che Anceschi ricorda come un grande interesse di Maldonado; "un disegno filiforme, fatto di un tratto essenziale, senza ombreggiature, senza effetti chiaroscurali" [Bistagnino 20 I 8, p. 98] [9]; un disegno la cui estetica risulta asciutta, intrinseca al contenuto ed estranea a stilismi.

Un disegno che anche nella dimensione autoriale e libera dagli strumenti tecnici della rappresentazione, svela una propensione verso la geometria, verso quello statuto teorico-scientifico che informa i molteplici processi di visualizzazione necessari alla rappresentazione 
dei contenuti progettuali nelle diverse fasi di ideazione e sviluppo del progetto (dall'analisi preliminare alla sintesi elaborativa) e, quindi, al suo progressivo formarsi in configurazioni complesse fino al definitivo concretizzarsi in prodotti [1 0].

L'espressione più evidente di questa propensione verso la geometria si attua chiaramente nel 'disegno costruttivo' o 'tecnico', con cui l'HffG indica quell'insieme di tecniche e metodi di rappresentazione sostanziali per la rappresentazione del progetto, soprattutto nell'ambito del design del prodotto. In particolare, nella visione che sarà poi esplicitata e sviluppata da Maldonado in Appunti sull'iconicità [Maldonado 1974] [ I I], emerge con precisione l'importanza attribuita alla conoscenza e alla capacità di gestione dell'intero ventaglio delle tecniche e degli accorgimenti tecnologici, che possono andare dalla prospettiva lineare, all'olografia alla raffinatissima modellistica tridimensionale, integrati da mezzi di rappresentazione quali la fotografia, la 'scrittura' nel senso

delle forme di materializzazione della scrittura come tipografia e 'lingua/linguaggio', nel senso della capacità di produrre testi.

In questo corpo di discipline, tutte confluenti verso l'ottimizzazione delle competenze tecnico-metodologiche e linguistiche funzionali al progetto, l'assonometria, in particolare, assume un ruolo privilegiato [12]. È infatti una forma proiettiva di grado basso, altamente operabile, oggettiva e antiretorica decisamente coerente, quindi, con i requisiti teorici, metodologici e d estetici formulati all'HfG.

Altrettanta efficacia e diffusione hanno le proiezioni ortogonali. Al di là delle evidenti applicazioni nel disegno tecnico per la descrizione del progetto, risultano un metodo basilare per la rappresentazione dei cosiddetti 'morfogrammi'. Forme grafiche, secondo la descrizione di Gui Bonsiepe, ritenute basilari per realizzare un processo elaborativo basato sul metodo. Con riferimento ai sistemi di classificazione formale sviluppati nell'ambito delle scienze biologiche, il metodo prevede la rappresentazione della gamma delle possibili soluzioni configurative, riferite a un certo argomento progettuale, basate su rapporti di similarità, per individuare affinità, ecc. anche indipendentemente da questioni evolutive, ovvero al di fuori di possibili condizionamenti 'stilistici' e in generale oltre una certa 'abitudine' a utilizzare consolidati rapporti formali e funzionali.

Dunque, una procedura grafica, di natura schematica, potenzialmente utile al processo progettuale, soprattutto nella fase di risoluzione di temi di dettaglio di una data configurazione, di cui, appunto, visualizzano le alternative.

Un procedimento che prevede la scomposizione dell'oggetto da studiare in zone di significazione formale, scelta, questa, che dipende da una valutazione socioculturale sensibile a specifiche istanze prestazionali e simboliche, ciascuna delle quali è studiata attraverso una serie di possibili varianti geometrico-funzionali.

Oltre a questo importante scenario di applicazioni, tornando a un discorso generale e di carattere teorico, bisogna aggiungere che la geometria, all'HfG, aveva anche un importante valore come processo elaborativo, penso alle trasformazioni geometriche e topologiche proposte nelle esercitazioni nell'ambito degli insegnamenti di Metodica della visione, che sono "una cosa un po' al confine fra Basic Design e una più generale disciplina delle Teorie e Tecniche della Rappresentazione" [Bistagnino 20 I 8, p. I | 3], una connessione, appunto, tra configurazione e rappresentazione [13].

Ricordo i procedimenti per la creazione controllata di forme; per fare un esempio, penso all'individuazione delle reti di punti per suddividere una superficie piana in elementi isomorfi e alle reti di figure piane usate per la scomposizione regolare di una superficie in configurazioni piane isomorfe, senza interstizi [I4].

Esercizi di tassellazione, che riguardano la creazione di forme geometriche con proprietà di collegamento senza soluzione di continuità in una ripetizione congruente (come quadrati o esagoni regolari).

Esercizi astratti solo nei principi geometrici generativi, concreti invece nelle applicazioni: penso al tracciamento di una pavimentazione o alla suddivisione di una superficie in sezioni congruenti ottenendo quindi una suddivisione senza sprechi.

Questa particolare visione della geometria come codice per l'organizzazione di segni bi/tridimensionali, naturale conseguenza dell'impostazione scientifico-metodologica della Scuola, 
Fig. I. Suddivisione di una superficie piana in elementi isomorfi, vi si individuano reti di punti: rete di punt generica (a forma di parallelogramma); rete d punti rettangolare; rete di punti rombica; rete di punti quadrata; rete di punti esagonale. Reti di figure piane. Gli indici danno il numero delle linee che convergono nei nodi di ogni figura isomorfa. 'elemento costruttivo delle figure piane

somorfe è indicato dal

icato dal retino.

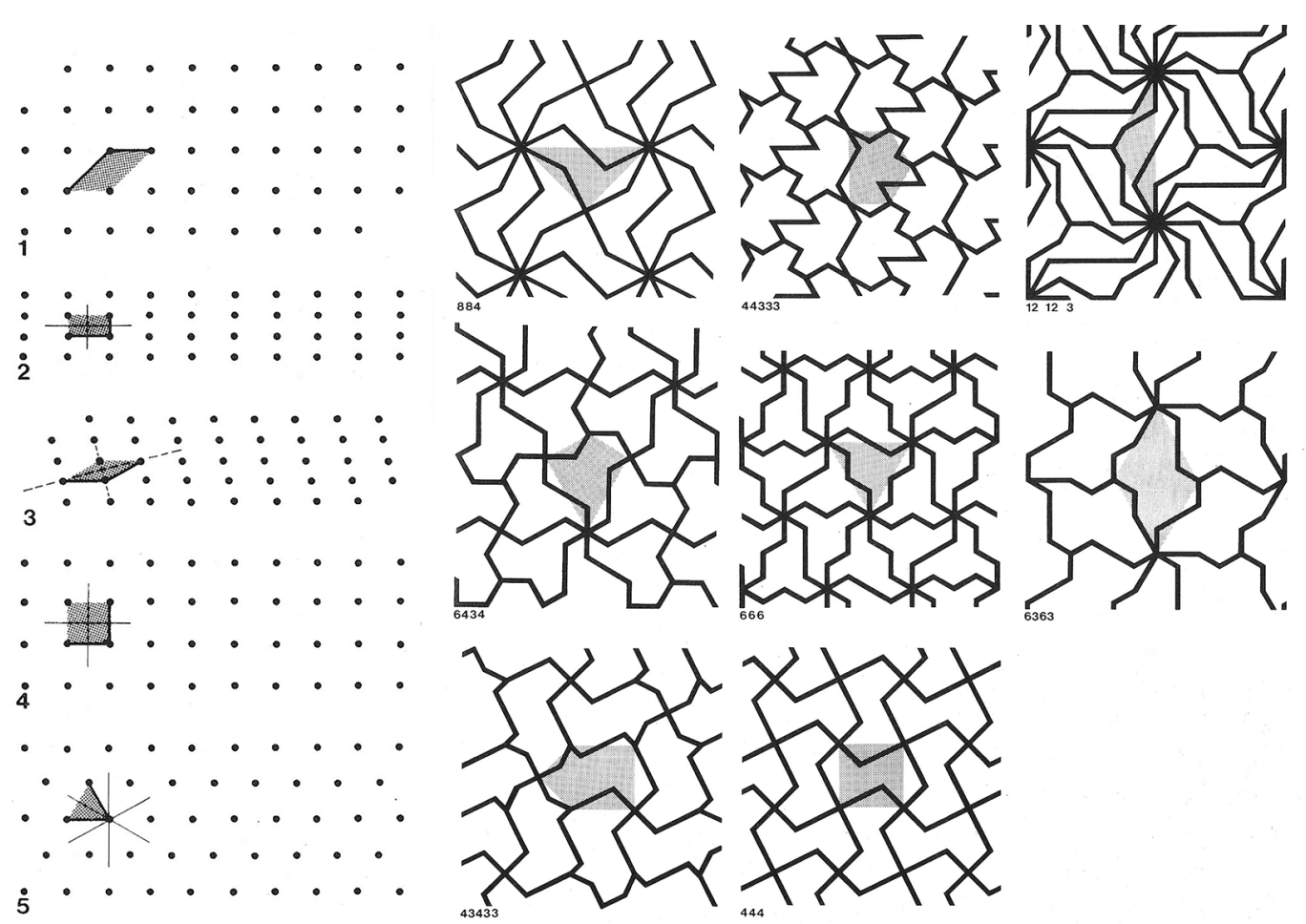

viene in larga misura introdotta da Maldonado, sulla base di alcune linee teoriche con cui entrò in contatto già prima dell'esperienza dell'HfG. In particolare, fra i testi che hanno orientato la sua attenzione verso le tematiche geometrico-scientifiche si ricorda: The Crisis in Intuition di Hans Hahn (1949), La Topologie di André Sainte-Laguë ( 1949), Anschauliche Topologie di Walther Lietzmann, Gestalt und Symmetrie di Karl Lothar Wolf e Dorothea Kuhn, e Was ist eine Kurve? di A.S. Parchomenko, oltre alle edizioni di Scientific American; ma ricordo anche il testo Flächenschluß. System der Formen lückenlos aneinanderschließender Flachteile di Heinrich Heesch e Otto Kienzle, alla base di molti argomenti teorici proposti da Gui Bonsiepe.

In questo scenario teorico, la geometria, pur se disciplina riferita alla matematica, e appunto insegnata a Ulm da matematici quali Fritz Emde - "un'autentica delizia pedagogica" secondo Giovanni Anceschi, "che insegnava gesticolando [...] e usava un libro meraviglioso di Ernst Schorner, Raumbild Lehrbuch der arstellenden Geometrie, con bellissime immagini stereoscopiche che guardate con gli occhialini bicromatici balzavano fuori dalla pagina" [Bistagnino 2018, p. I I2] [15] -, assume, nell'ambito dei problemi di configurazione un valore operazionale-visivo che ne attesta il legame imprescindibile con il segno grafico e, conseguentemente, con la disciplina del disegno. In altri termini, nel disegno, fra codici visivi e operativi, la geometria trova un prolifico laboratorio dove acquisire anche significative valenze estetiche, quell'estetica scientifica che, appunto contraddistingue Ulm.

Una vera e propria teoria della configurazione, sostanzialmente incentrata sulla "teoria della simmetria" intesa come relazione coerente tra forme uguali o simili [ 16].

Si tratta di operazioni geometriche, di natura generativa che permettono di elaborare scientificamente configurazioni dotate di 'coerenza formale'. Penso, ad esempio, all'interesse verso lo studio delle curve di Peano, proposte come esercizio didattico proprio da Tomàs Maldonado, oppure penso agli esercizi di simmetria realizzati attraverso operazioni geometriche elementari di traslazione, rotazione, riflessione speculare e dilatazione nei corsi di William Huff.

Infine, un ulteriore cenno ai raster, configurazioni a cui fa riferimento Maldonado, contraddistinte da una natura digitale, un digitale senza computer, una sorta di avanguardia digitale. 
Fig. 2. Giovanni Anceschi (assistente pedagogico), chemi concettual n preparazione del programma in multi-proiezione di presentazione della Scuola ai visitatori, 1967
"Il raster, termine traducibile in italiano con l'espressione retino o trama, è infatti una successione di pixel, un plottaggio di punti. Ogni punto viene ridotto o ingrandito, schiarito o scurito, colorato, ecc. come avviene con i pixel [...]. Quindi un digitale un po' metaforico che si propone in una dimensione estremamente artigianale, una pratica a cui Herbert Lindinger attribuiva perfino un valore meditativo" [Bistagnino 2018, p. 120].

Da un altro punto di vista, i raster in quanto pratica configurativa inserita in una "deologia anti-arte" [Bistagnino 20 I 8, p. 123] sembrano rappresentare come gli esercizi di simmetria, un'attività metaprogettuale con cui produrre forme non immediatamente utilitaristiche, nelle quali esplorare trame e spazialità.

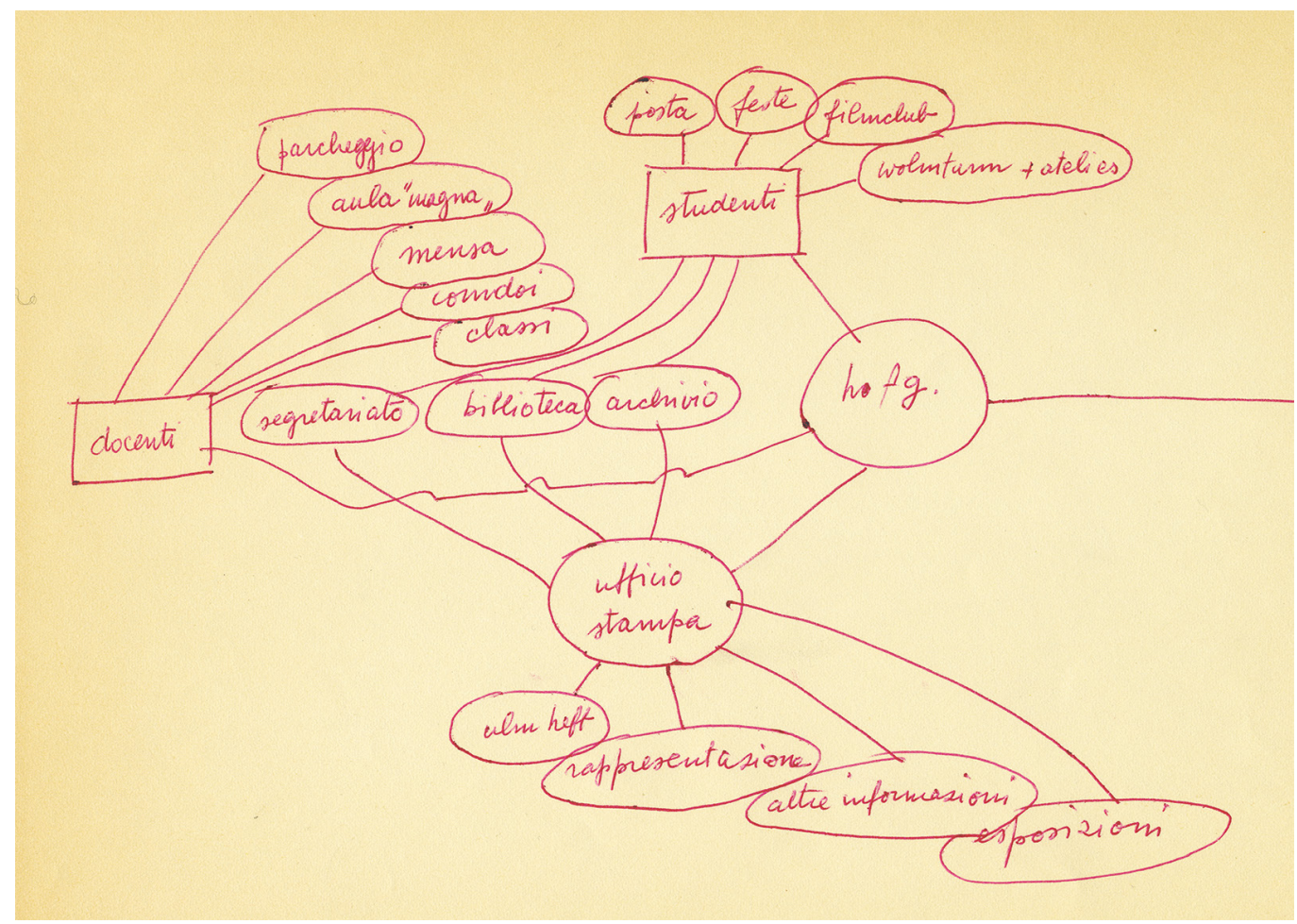

\section{Conclusioni}

II disegno così come pensato, insegnato e fruito all'HfG, sembra attuare molteplici connessioni che si esprimono su più livelli.

Connette l'astrazione matematico-scientifica con la prassi, è infatti metodo grafico per lo studio di configurazioni bi/tridimensionali.

Connette la teoria e il progetto; le modalità rappresentative praticate nelle esercitazioni propedeutiche più volte menzionate in questo saggio, costituiscono un sostanzioso riferimento per il progetto con il quale, spesso, intrattengono evidenti rapporti procedurali, talvolta anche di similarità visiva.

Connette il passato e il presente, stabilendo linee di coerenza o discontinuità, di citazione o anticipazione. Ricordo ancora il rapporto con il Bauhaus, progressivamente sottoposto a revisioni che si sono concretizzate nell'offerta formativa di matrice scientifica, attuata già a partire dalla ridefinizione del Corso Fondamentale. Ma ricordo anche i sistemi di configurazione anticipatori della cultura dell'informatizzazione dei processi generativi e automatici nel campo del progetto.

Connette infine, coniugandole e armonizzandole, una molteplicità di valenze - etica, estetica, scientifica, metodologica - anticipando la moderna cultura progettuale. 


\section{Note}

[I] Bistagnino Enrica, Conversazione sul Disegno con Tomàs Maldonado [Bistagnino 20 I8, pp. 87-89].

[2] A tale riguardo cfr. la prefazione di Giovanni Anceschi al libro E. Bistagnino, II Disegno nella Scuola di Ulm, Milano: FrancoAngeli, 2018, pp. 9-10.

[3] Per approfondimenti: Bistagnino Enrica, Conversazione sul Disegno a Ulm con Giovanni Anceschi [Bistagnino 20 I 8, pp. 91 - I28].

[4] Ricordo, ad esempio, la Colonia di artisti di Darmstadt ( 190 I), il Werkbund ( 1907), L'A\&G ( I 883) fondata dall'ingegnere tedesco Emil Rathenau e trasformata da Peter Beherens (tra il 1906 e il 1914) in un laboratorio culturale, la Scuola d'arte applicata di Weimar (1915) fondata da Henry van de Velde, II Bauhaus. Per approfondimenti si veda: de Fusco Renato, Germania-U.S.A. 1900-1929 [de Fusco 1985, pp. 75-160].

[5] Nella fase inziale, la Scuola, grazie, soprattutto, alla linea culturale autorevolmente proposta da Max Bill traccia una sostanziale linea di coerenza con il Bauhaus, dove era stato studente, di cui ribadisce, in modo pieno ed esplicito, gli obiettivi e i metodi formativi. Nel 1952 Max Bill dichiara: "Consideriamo l'arte come la più alta forma di espressione della vita, ed è nostra intenzione organizzare la vita come un'opera d'arte. Come a suo tempo dichiarò Van de Velde, vogliamo combattere il brutto con l'aiuto del bello, del buono, del pratico. In quanto successore dell'istituzione artistica weimariana di Van de Velde, il Bauhaus ebbe lo stesso scopo. Se a Ulm andiamo un po' più avanti di allora, attribuendo maggiore importanza alla progettazione di oggetti, ampliando l'urbanistica e la progettazione, adeguando ai livelli attuali il settore delle comunicazioni visive e infine aggiungendo una sezione di informazione, ciò deriva naturalmente dalle esigenze del nostro tempo" [Bistagnino 20। 8, p. 22].

[6] Discorso pronunciato all'HfG di Ulm da Tomàs Maldonado, in occasione dell'inaugurazione dell'a.a. 1957-1958. In Herbert Lindinger (a cura di). (1988). La Scuola di Ulm. Genova: Costa \& Nolan, p. 22.

[7] L'estetica scientifica sostenuta da molti ulmiani, in primis da Tomàs Maldonado, sembra riferibile ad alcuni temi introdotti dal dibattito filosofico degli anni Venti, in particolare dal neopositivismo logico del Circolo di Vienna, da figure quali Rudolf Carnap, Otto Neurath ecc.

[8] A titolo d'esempio, ricordo il contributo didattico di Horst W. Rittel, matematico, fisico e sociologo attivo a Ulm dal 1958 al 1963, che, come documentato dal piano di studi 1958/59, insegna Metodologia (oltre ai Corsi di Teoria della scienza e Analisi operazionale) in un corso di 70 ore al primo anno (lezioni comuni a tutte le sezioni). Segnalo poi, dal |96। al 1966, il contributo di Abraham A. Moles, laureato in Filosofia e Scienze naturali, che, insieme a Kurd Alsleben, insegna Metodologia in due corsi, ciascuno di 60 ore, al primo e al secondo anno (lezioni comuni a tutte le sezioni). Per approfondimenti: Lindinger 1988, p. 218$]$.

[9] Bistagnino Enrica, Conversazione sul Disegno a ULM con Giovanni Anceschi [Bistagnino 20 I8, p. 98].

[I0] Per approfondimenti: Bistagnino Enrica, Teoria e didattica del Disegno [Bistagnino 20 I 8, p. 73- I28].

[I I] Maldonado Tomàs, Appunti sulliconicità [Maldonado 1974].

[12] Giovanni Anceschi riferisce: "Aicher additava, la Kavalier-Perspektive combinata con il punto di vista accidentale, come la formula preferibile come la formula preferibile, in quanto operabile e - diciamo cosi - oggettiva. Del resto, sono convinto che un'indagine storica metterebbe in rilievo, addirittura in tutta la tradizione del moderno, la predilezione per forme proiettive di grado basso e quindi caratterizzate da un alto coefficiente di operabilità a scapito della loro immediatezza interpretativa come avrebbe detto Abraham Moles. Le proiezioni ortogonali, l'assonometria e, al massimo, la prospettiva cavaliera: proiezioni semplici e operabili, scelte anche per una certa sospettosità nei confronti della retorica manipolatoria implicita nella grande prospettiva" [Bistagnino 20|8, p. ||2].

[13] si veda: Bistagnino 2018, p. 113.

[14] Per approfondimenti: Bonsiepe 1993, prima edizione 1975, pp. 169-173.

[15] Bistagnino Enrica, Conversazione sul Disegno a ULM con Giovanni Anceschi [Bistagnino 20 I 8, p. I I 2].

[16] A tale riguardo è particolarmente esaustiva la descrizione curata da Gui Bonsiete sulle classi di somiglianza tra forme e sulle operazioni geometriche elementari per trasformare le forme in configurazioni complesse.

L'uguaglianza o somiglianza tra forme è riconducibile, secondo Gui Bonsiepe alle seguenti classi: I classe: Isometria.

Isomorfi si dicono quegli elementi che hanno la stessa forma e la stessa dimensione.

Esempio: una palla da tennis costituita da due metà uguali.

II classe: Omeometria. Omeomorfi si dicono quegli elementi che hanno la stessa forma ma dimensioni diverse. Esempio: un assortimento di chiavi per bulloni.

III classe: Singenometria. Singenomorfi si dicono quegli elementi deformati in modo affine o proiettivo. Esempio: un parallelogramma o un poligono irregolare sono deformazioni rispettivamente affine e proiettiva del rettangolo.

IV classe: Catametria. Catamorfi si dicono quegli elementi che non sono né congruenti né affini, ma che sono legati da un comune rapporto interfigurale. Esempio: un alfabeto, le cui lettere hanno forme assai diverse, ma che grazie alla similarità dei particolari formali sono recepite come appartenenti a un sistema.

$\checkmark$ classe: Eterometria. Eteromorfi si dicono quegli elementi che non dimostrano un rapporto interfigurale, ma intrafigurale. Esempio: un'opera di Henry Moore o un apparecchio televisivo.

VI classe: Ametria. Amorfi si dicono quegli elementi che non hanno rapporti interfigurali né intrafigurali. L'ametria costituisce un caso limite fra le classi di simmetria; essa possiede solamente significato teorico nell'ambito di una tassonomia tendente alla completezza.

Le operazioni geometriche elementari, eventualmente combinate insieme, per generare articolazioni compositive lineari (su un asse), piane (su due assi), spaziali (su tre assi) sono:

- traslazione: uno spostamento semplice e lineare di una parte elementare lungo una direttrice di traslazione;

- rotazione: movimento circolare di una parte elementare intorno a un asse;

- riflessione speculare: ribaltamento dei dati di una parte elementare su un asse o un piano di riflessione;

- dilatazione: mutazione uniforme di una parte elementare da un punto prefissato (centro di dilatazione). 
Operazioni combinate:

rotazione più traslazione; rotazione più riflessione; traslazione più riflessione; traslazione più dilatazione; dilatazione più riflessione; dilatazione più rotazione; riflessione più dilatazione più traslazione; dilatazione più rotazione più riflessione; dilatazione più rotazione più traslazione; rivoltamento o inversione (rovesciamento dall'interno all'esterno).

In Bistagnino 2018, pp. 80-83.

\section{Riferimenti bibliografici}

Arbel Benjamin (1996). Colonie d'oltremare. In Menniti Ippolito Antonio, Benzoni Gino (a cura di). Storia di Venezia. Dalle origini alla caduta della Serenissima, V, II Rinascimento. Roma: Istituto della Enciclopedia italiana, vol. 5, pp. 947-985.

Arbel Benjamin (2013). Venice's maritime Empire in the early modern period. In Eric R. Dursteler (a cura di). A Companion to venetian history, 1400-1 797. Leiden: Brill's Companions to European History, pp. I25-254.

Gherado Ortalli, Oliver Jens Schmitt (a cura di). (2009). Balcani Occidentali, Adriatico e Venezia fra XIII e XVIII secolo/ Der Westliche Balkan, Der Adriaraum Und Venedig $13^{\text {th }}-18^{\text {th }}$. Jahrhundert. Venezia-Vienna: Austrian Academy of Sciences.

Hocquet Jean Claude ( 1989). Fiscalité et pouvoir colonial.Venise et le sel Dalmate aux XV et XVI siècles. In Balard Michel (ed.) Etat et colonisation au Moyen Âge. Lyon: La Manufacture, pp. 277-3I6.

Krekić Bariša (1995). Venezia e l'Adriatico. In Arnaldi Girolamo, Cracco Giorgio, Tenenti Alberto (a cura di). Storia di Venezia Dalle origini alla caduta della Serenissima, III, La formazione dello stato patrizio. Roma: Istituto della Enciclopedia italiana, vol. 3 , pp. $51-85$.

Paladini Filippo Maria (2002). Un caos che spaventa. Poteri, territori e religioni di frontiera nella Dalmazia della tarda età veneta. Venezia: Marsilio Editore.

Praga Giuseppe (198I). Storia di Dalmazia. Milano: Dall'Oglio.

Parrinello Sandro, Picchio Francesca (a cura di). (2019). Dalmazia e Montenegro. Le fortificazioni Venete nel Bacino del Mediterraneo Orientale. Procedure per la conoscenza e la Documentazione Digitale del Patrimonio Storico Fortificato. Pavia: Pavia University Press

\section{Autore}

Enrica Bistagnino, Università di Genova, enrica.bistagnino@unige.it

Per citare questo capitolo: Bistagnino Enrica (2020). Connessioni storiche fra il disegno e il design. Qual è la lezione della Scuola di Ulm? Historical connections between drawing and design. What is the lesson of the Ulm School? In Arena A. Arena M. Brandolino R.G. Colistra D. Ginex G., connections between drawing and design. What is the lesson of the Ulm School?. In Arena A., Arena M., Brandolino R.G., Colistra D., Ginex G., Mediati D., Nucifora S., Raffa P. (a cura di). Connettere. Un disegno per annodare e tessere. Atti del $42^{\circ}$ Convegno Internazionale dei Docenti delle
Discipline della Rappresentazione/Connecting. Drawing for weaving relationships. Proceedings of the 42 th International Conference of Representation 


\title{
Historical Connections between Drawing and Design. What is the Lesson of the Ulm School?
}

\author{
Enrica Bistagnino
}

Abstract

Hochschule für Gestaltung, Ulm, 1950-1968, place of theoretical foundation of design, school, moment of 'unprejudiced' confrontation, space for dialogue with the industrial world, contribution to the democratic re-education of Germany.

With reference to these and other meanings, the essay deals with the theme of Ulm Drawing, to deepen some theoretical and procedural issues, and highlight their significance in the configuration processes.

A 'classic' reference of design which, for the key role exercised by Ulm for the culture of the project, makes every re-reading be a reading of discovery.

It is the multiple interpretative proposals, in fact, that help to clarify the HfG and offer it as a model to be applied, modified or denied.

The relationship between the theme and 'connecting' covers two levels: the first il the space-time sphere, the connection with a theoretical-didactic experience in a distant geographical and historical context that produce a cultural distance; the second refers the relationship between drawing and project. We want to point out the anticipatory scope with respect to the generative dimension of digital representation, a "digitale ante litteram", made through a mix of scientific and artisan dimension. The study method provides for the description of the design through a top / down process. The essay, starting from the reference to some theoretical andò cultural issues, evolves towards technical-methodological themes, up to describe of the application practice.

Keywords

drawing for design, history of representation, Hfg of Ulm, methodology for design, methodology.

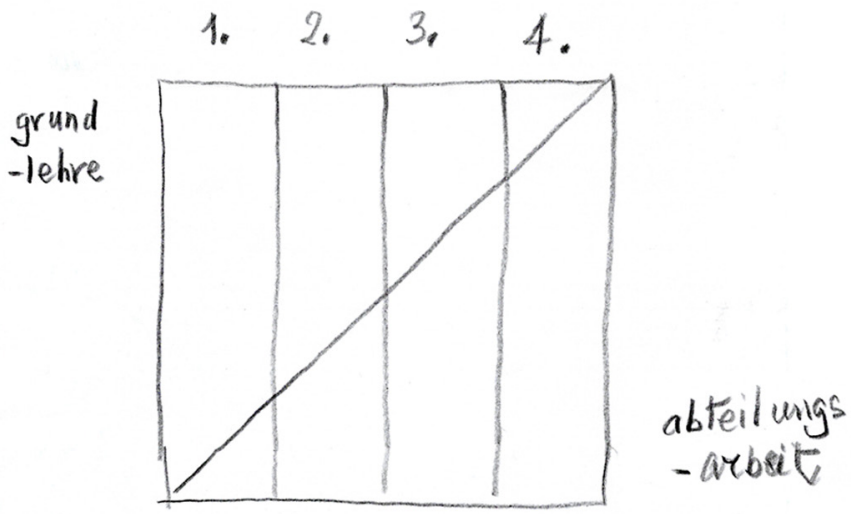




\section{Introduction}

The drawing al the HfG of Ulm was an important discipline.

It is a thought that emerges from a conversation with Tomàs Maldonado [I], -by the most ones indicated as one of the main protagonists of the HfG, theoretical but also pragmatic and pedagogical founder [2]- and further reaffirmed by Giovanni Anceschi [3].

Having said that, before describing the HfG drawing, its 'forms' and its role, it is necessary to remember, albeit in summary, some building blocks of Ulmian thought, in particular that following the theoretical renewal introduced by Tomàs Maldonado. In fact, these are central topics for the definition of the content and teaching methods of the teachings carried out at the Hfg, including, of course, those of representation.

I will therefore mention some aspects which, from different perspectives, seem paradigmatic of a radical and comprehensive cultural revision brought from Ulm to the design of the second half of the twentieth century; I will refer, in particular, to the methodological design process and its pedagogy, to the idea of object, and to its ethical and aesthetic values.

\section{A new design idea}

The most significant theme is undoubtedly the change in the vision of design, which begins to mature and be explicited in the reviewing of the theories and teaching of the Bauhaus (1919-1933), the training experience, among those of the consolidated German tradition [4] closer to the HfG [5], and which certainly follows from the general objectives of the School -the improvement of society, responding to material and immaterial needs, and the democratic reeducation of the German people in the dramatic scenario of the second post-war period-.

The loss of the initial continuity with the School of Gropius, determined by a group of young progressive teachers, Otl Aicher, Hans Gugelot, Tomàs Maldonado, who substantially contrasted the subjective and empirical practice underlying the learning by doing and the figure of designer-artist determined by the training model, is definitively clarified by the inaugural speech delivered by Maldonado, the new rector of the School. "The attempt to continue the Bauhaus literally would amount to an effort of mere restoration, the best of those who belonged to the Bauhaus will certainly agree in recognizing that a continuation of the Bauhaus today implies being in a certain sense against the Bauhaus. We only assume its progressive, unconventional attitude, the aspiration to make a contribution to society, in the respective historical situation. In this sense, and only in this sense, we continue the work of the Bauhaus" [Maldonado 1957] [6].

In relation to this audacious proof of autonomy, Maldonado and the other progressive teachers declare that the design must cover a wide range of products (including means of transport, household appliances, medical devices, as well as information systems, etc.) and, therefore, must be the result of a renewed planning, based on analysis, design and evaluation processes appropriate to the level of complexity as well as to the function of the products themselves.

From this general redefinition of the idea of design, here only hinted, follows that profound revision, referred, above all, to the themes of ethics, aesthetics, method and science, which is pervasive of education, in all its expressions, including, as we shall see, that relating to drawing.

(On the previous page): Giovanni Anceschi, graphic scheme of the didactic-pedagogical model of the School of Ulm. Freehand drawing Ulm. Freehand drawing Anceschi (Milano, 26 February 20|8).
According to the new ethical vision of design, oriented towards the social design of the environment, Ulm identifies in the collaboration of designers, engineers, scientists, research laboratories, areas of production and trade, a fundamental and innovative model for moving from a conception mainly formal of the product to a functional based on a logical-deductive methodology, through which, precisely, to produce objective values. 
If the design is, therefore, the design of the 'interior', of the structure and of the operation, if the technical design of the objects is central, then there will be important implications in relation to the aesthetic question. The design thus understood is evidently foreign to the sphere of taste, and this at least for two reasons.

First of all, due to the fact that the ideational process, as conceived in UIm, 'inhibits' processes for the elaboration of the form independent from the technical-construction design of the product itself. Then, because the continuous updating of taste according to criteria that do not depend on the real need for product improvement, but on the need for novelty mainly motivated by market logic, would ultimately generate the decline of the taste itself and the departure from technical improvement- construction of the products towards which the project must aim.

A design paradox would be created: the planning of wear, of obsolescence, and the consequent continuous redesign of the external shape of the objects.

The aesthetic question, which among other things still ignites the criticism of the Bauhaus -responsible, according to Maldonado, for having promoted a rationalist aesthetic of industrial production, otherwiswe that of having suppressed an artistic repertoire, but of having replaced it with another as well artistic- and the strong ethical tension feed research by directing it towards the definition of data analysis and management processes, functional to the elaboration and development of project contents which is a methodological processing space aimed at determining objective, 'participatory' solutions and verifiable [7].

To support this design approach, teaching is enriched with scientific teachings, often taught by mathematicians and philosophers [8], such as, by way of example: Methodology, Combinatorial analysis, Game theory, Information theory, Mathematical logic, Commutative algebra, Linear programming, Systems theory, Queue theory, Combinatorial topology.

According to this didactic revision, the HfG study plans systematise the educational offer around three scientific areas -the Basic Sciences (Mathematical Analysis, Cybernetics, Physics, Methodology, Theory of Science, Theory of Perception, Construction Design, Writing, etc. ); Social Sciences (Linguistics, Semiotics, Sociology, Psychology, Economics, Politics, etc.); History Sciences (History of Civilization, History of Cinema, History of Industrial Design, History of Literature etc.)- supplemented by practice.

Within a formative conception that combines neo-positivism and pragmatism, that dialectical relationship between thought and action takes place, which, according to Maldonado's model, must provide for a progressive replacement of theoretical teachings with practical (design) ones.

\section{The Drawing}

Even the drawing, like the design to which it is intrinsically linked, is clearly affected by the overall ethical, aesthetic, methodological vision of the $\mathrm{HfG}$.

This occurs on different levels -from that of the graphic sign to the technical-methodological, to the conformative one- and concerns disciplinary expressions in the strict sense as well as those manifestations that are strongly intertwined with contiguous languages, I think, in particular, to the design for visual communication.

So what is the drawing in Ulm? What are its declinations? What are its connections with the elaborative processes of design?

According to Tomàs Maldonado's thought, drawing with a capital D, therefore an "intellectual rather than graphic" drawing, we could say understood in the Albertian meaning of lineamenta, is the textualization of the project language, its writing; in other words, it is the condition of the project, it is a substantial form, a place of construction and elaboration of the idea.

An idea of drawing, referable to the heuristic drawing practiced freehand, which Anceschi remembers as a great interest of Maldonado; "A filiform drawing, made of essential line, without shading, without chiaroscuro effects" [Bistagnino 20।8, p. 98] [9]; a drawing whose aesthetics are dry, intrinsic to the content and extraneous to stylisms. 
A drawing that also in the authorial dimension and free from the technical tools of representation, reveals a propensity towards geometry, towards that theoretical-scientific statute that informs the multiple visualization processes necessary for the representation of the project contents in the various phases of conception and development of the project (from the preliminary analysis to the elaborative synthesis) and, therefore, to its progressive formation in complex configurations up to the final realization in products [ 10$]$.

The most evident expression of this propensity towards geometry is clearly realized in the 'constructive' or 'technical' design, with which the HfG indicates that set of techniques and methods of substantial representation for the representation of the project, especially in the context of product design. In particular, in the vision that will then be explained and developed by Maldonado in Appunti sull'iconicità [Maldonado 1974] [I I], the importance attributed to the knowledge and ability to manage the entire range of techniques and technological devices emerges with precision. They can go from linear perspective, to holography to refined three-dimensional modeling, integrated by means of representation such as photography, the 'writing' in the sense of the materialization forms of writing such as typography and language / language", in the sense of the ability to produce texts.

In this body of disciplines, all converging towards the optimization of the technical-methodological and linguistic skills functional to the project, axonometry, in particular, takes on a privileged role [12]. It is in fact a low-grade, highly operable, objective and anti-rhetorical projective form that is decidedly consistent, therefore, with the theoretical, methodological and aesthetic requirements formulated at HfG.

The orthogonal projections are just as effective and widespread. Beyond the obvious applications in the technical drawing for the description of the project, they are a basic method for the representation of the so-called 'morphograms'. Graphic forms, according to the description of Gui Bonsiepe, considered basic to carry out a processing process based on the method. With reference to the formal classification systems developed in the field of biological sciences, the method provides for the representation of the range of possible configurative solutions, referring to a certain design topic, based on similarity relationships, to identify affinities, etc. also independently from evolutionary issues, that is outside of possible 'stylistic' influences and in general beyond a certain 'habit' to use consolidated formal and functional relationships.

Therefore, a graphical procedure, of a schematic nature, potentially useful for the design process, especially in the phase of solving detailed themes of a given configuration, of which, in fact, they display the alternatives.

A procedure that involves the breakdown of the object to be studied into areas of formal significance, chosen, this, which depends on a socio-cultural evaluation sensitive to specific performance and symbolic instances, each of which is studied through a series of possible geometric variants functional.

In addition to this important scenario of applications, returning to a general and theoretical discourse, it must be added that geometry, at the HfG, also had an important value as a processing process, I think of the geometric and topological transformations proposed in the exercises in the field of teachings of Methodology of vision, which are "something a bit on the border between Basic Design and a more general discipline of Theories and Techniques of Representation" [Bistagnino 20 I8, p. II3], a connection, in fact, between configuration and representation [13].

I remember the procedures for the controlled creation of forms; to give an example, I think of identifycation the networks of points to divide a flat surface into isomorphic elements and to the networks of flat figures used for the regular decomposition of a surface into isomorphic flat configurations, without interstices [14].

Tessellation exercises, which concern the creation of geometric shapes with seamless connection properties in a congruent repetition (such as squares or regular hexagons).

Abstract exercises only in generative geometric principles, instead concrete in applications: I think about tracing a pavement or dividing a surface into congruent sections thus obtaining a division without waste. 
Fig. I. From left to right: Subdivision of a flat surface into isomorphic elements, point networks are identified: generic point network (in the shape of a parallelogram); rectangular dot network; rombic point network: remor square point network, hexagonal point network Networks of flat figures. The indices give the number of lines that converge in the nodes of each isomorphic figure. The constructive element of the isomorphic plane figures is indicated by the grey area.

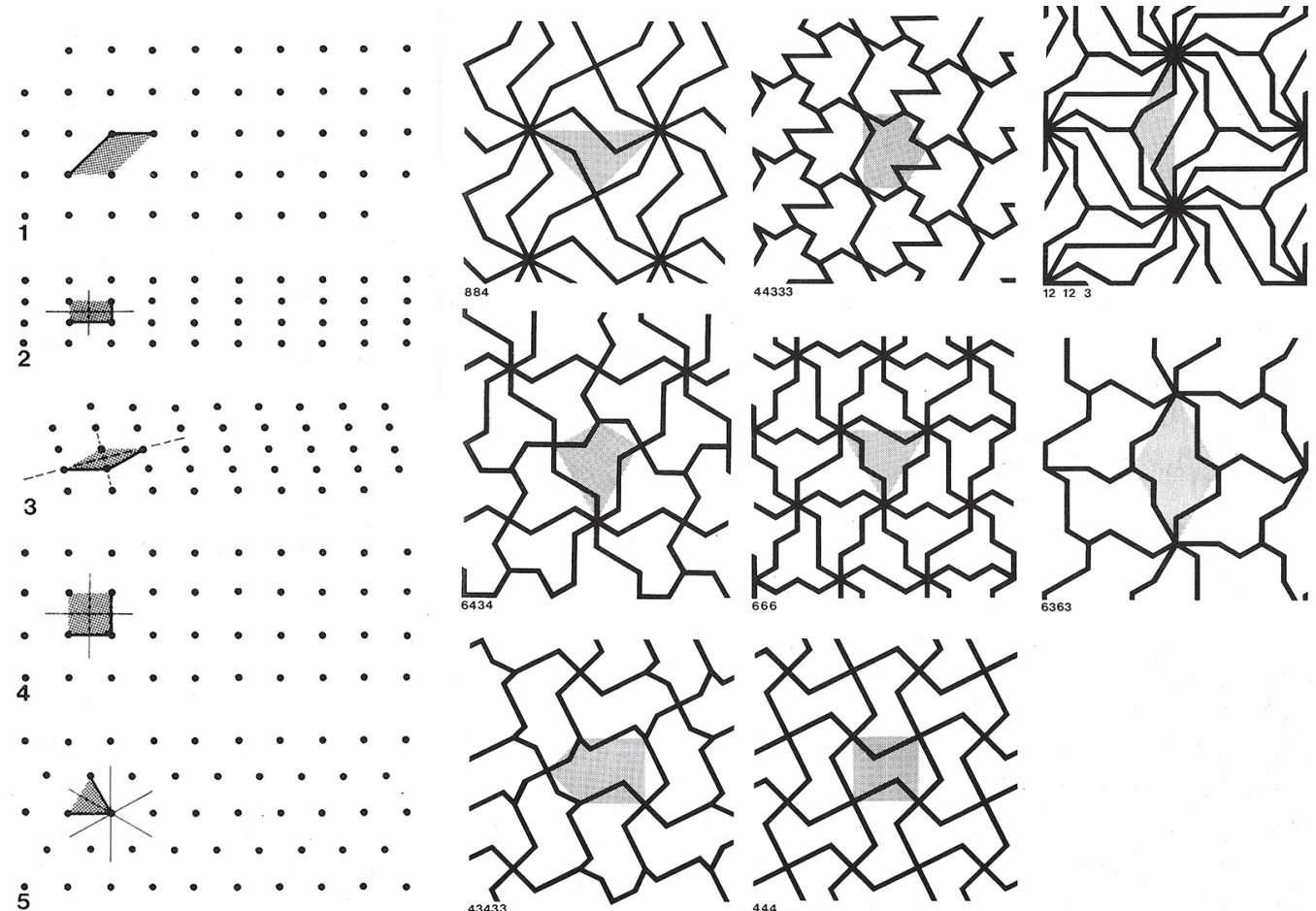

This particular vision of geometry as a code for the organization of two / three-dimensional signs, a natural consequence of the scientific-methodological approach of the School, is largely introduced by Maldonado, on the basis of some theoretical lines with which he came into contact before experience of the HfG. In particular, among the texts that have oriented his attention towards geometric-scientific issues, we remember: The Crisis in Intuition by Hans Hahn ( 1949), La Topologie by André Sainte-Laguë (1949), Anschauliche Topologie by Walther Lietzmann, Gestalt und Symmetrie by Karl Lothar Wolf and Dorothea Kuhn, and Was ist eine Kurve? by A.S. Parchomenko, in addition to the editions of Scientific American; but I also remember Flächenschluß. System der Formen lückenlos aneinanderschließender Flachteile by Heinrich Heesch and Otto Kienzle, behind many theoretical arguments proposed by Gui Bonsiepe.

In this theoretical scenario, geometry, although a discipline related to mathematics, and indeed taught in Ulm by mathematicians such as Fritz Emde - "an authentic pedagogical delight" according to Giovanni Anceschi, "who taught by gesticulating [...] and used a wonderful book of Ernst Schorner, Raumbild Lehrbuch der arstellenden Geometrie, with beautiful stereoscopic images that if looked using bichromatic glasses jumped out of the page" [Bistagnino $2018, p .112]$ [15]-, assumes, in the context of configuration problems, an operational-visual value which attests to its essential link with the graphic sign and, consequently, with the discipline of drawing. In other words, in the design, between visual and operational codes, geometry finds a prolific laboratory where it can also acquire significant aesthetic values, that scientific aesthetic which, in fact, distinguishes UIm.

A real theory of configuration, substantially focused on the "theory of symmetry" understood as a coherent relationship between equal or similar forms [16].

These are geometric operations, of a generative nature that allow scientifically elaborating configurations with "formal coherence". I think, for example, of the interest in the study of Peano curves, proposed as a didactic exercise by Tomàs Maldonado, or I think of the symmetry exercises carried out through elementary geometric operations of traslation, rotation, specular reflection and dilation in the courses of William Huff.

Finally, a further mention to the raster, configurations to which Maldonado refers, characterized by a digital nature, a digital without a computer, a sort of digital avant-garde. "The 
Fig. 2. Giovanni Anceschi (pedagogical assistant) conceptual schemes in preparation of the multi-projection program of presentation of the School to visitors, 1967 raster, a term translatable into Italian with the expression texture, is in fact a sequence of pixels, a plotting of points. Each point is reduced or enlarged, lightened or darkened, colored, etc. as happens with pixels [...]. So a slightly metaphorical digital that proposes itself in an extremely artisanal dimension, a practice to which Herbert Lindinger even attributed a meditative value" [Bistagnino 2018, p. 120].

From another point of view, the raster as a configuration practice inserted in an "anti-art ideology" [Bistagnino 2018, p. 123], seem to represent how the exercises of symmetry, a metaproject activity with which to produce forms that are not immediately utilitarian, in which to explore plots and spatiality.

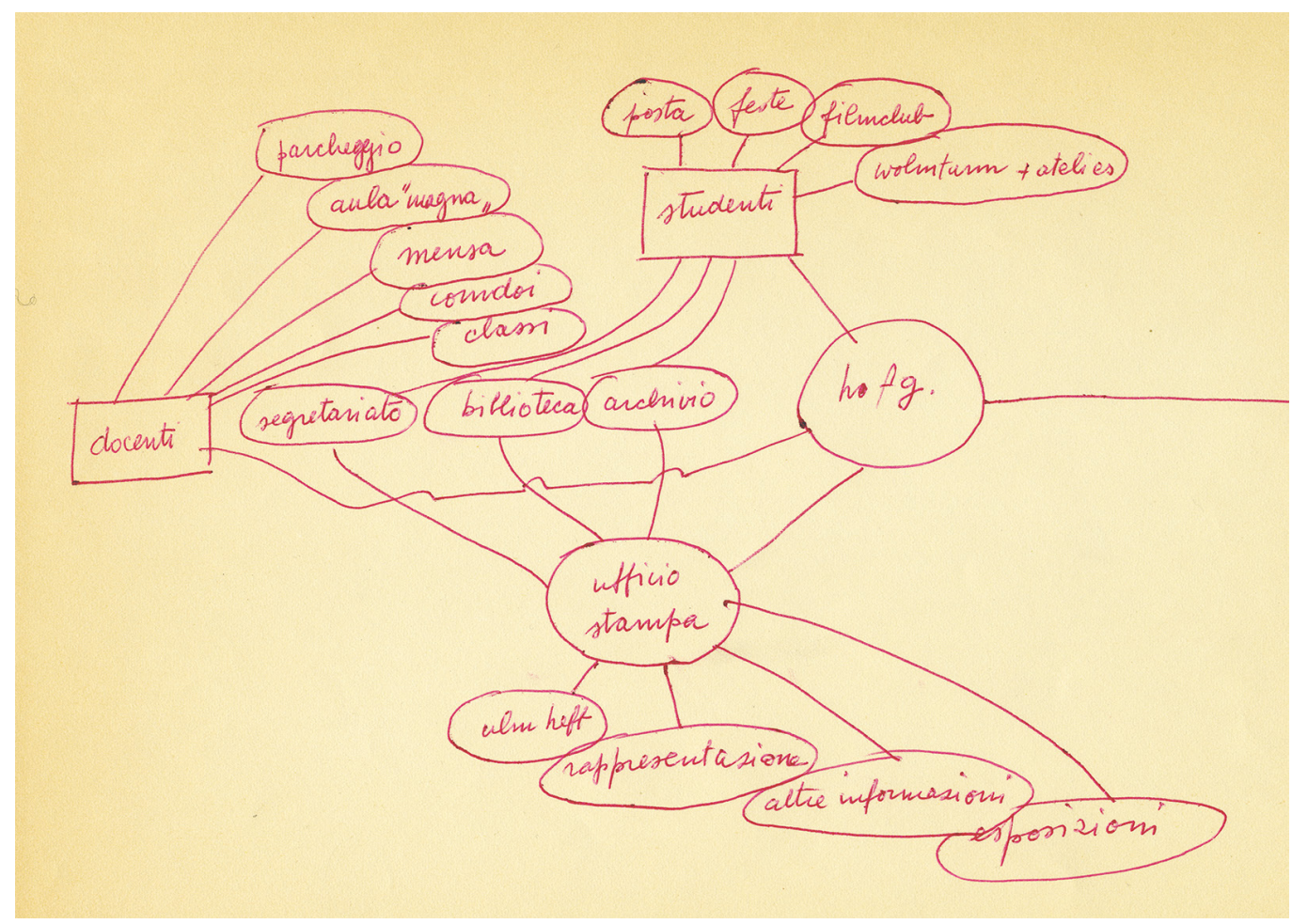

\section{Conclusions}

The design as conceived, taught and used at the HfG seems to implement multiple connections that are expressed on several levels.

It connects mathematical-scientific abstraction with practice, it is in effect a graphic method for the study of two / three-dimensional configurations.

It connects theory and project; the representative methods practiced in the preparatory exercises mentioned several times in this essay, constitute a substantial reference for the project with which, often, they have evident procedural relationships, sometimes even of visual similarity.

It connects the past and the present, establishing lines of coherence or discontinuity, of quote or anticipation. I still remember the relationship with the Bauhaus, which was progressively subjected to revisions which took the form of a scientific formative offer, already implemented since the redefinition of the Fundamental Course. But I also remember the anticipatory configuration systems of the culture of computerization of generative and automatic processes in the field of the project.

Finally, it connects, combining and harmonizing them, a multiplicity of values -ethical, aesthetic, scientific, methodological- anticipating modern design culture. 


\section{Notes}

[I] Bistagnino Enrica, Conversazione sul Disegno con Tomàs Maldonado [Bistagnino 20 I8, pp. 87-89].

[2] In this regard of. the preface by Giovanni Anceschi to the book E. Bistagnino, II Disegno nella Scuola di Ulm, Milano: FrancoAngeli, 2018 , pp. 9- 10.

[3] For further details: Bistagnino Enrica, Conversazione sul Disegno a Ulm con Giovanni Anceschi. In E. Bistagnino, ivi, pp. 9 I - I 28.

[4] I remember, for example, the Colonia di artisti di Darmstadt (I90 I), the Werkbund (I907), the A\&G (I 883) founded by the German engineer Emil Rathenau and transformed by Peter Beherens (between 1906 and 1914) into a laboratory cultural, the Scuola d'arte applicata of Weimar (1915) founded by Henry van de Velde, The Bauhaus. For further details see: de Fusco Renato, Germania-U.S.A. 1900-1929 [de Fusco 1985, pp. 75-160].

[5] In the initial phase, the School, thanks above all to the cultural line authoritatively proposed by Max Bill, traces a substantial line of coherence with the Bauhaus, where Bill had been a student, of which it is reaffirms, in a full and explicit way, the objectives and training methods. In 1952 Max Bill declares: "We consider art as the highest form of expression of life, and it is our intention to organize life as a work of art. As Van de Velde declared in his time, we want to fight the ugly with the help of the beautiful, the good, the practical. As a successor of Van de Velde's Weimarian artistic institution, the Bauhaus served the same purpose. If in Ulm we go a little further than then, attaching greater importance to the design of objects, giving more value to the urban planning and project, adapting the visual communications sector to current levels and finally adding an information section, this naturally derives from the needs of our time" [Bistagnino 20 I 8, p. 22].

[6] Speech given by Tomàs Maldonado at the HfG in Ulm, on the occasion of the inauguration of the a.y. $1957-1958$.

In Herbert Lindinger (edited by). (1988). La Scuola di Ulm. Genova: Costa \& Nolan, p.22.

[7] The scientific aesthetics supported by many Ulmians, in primis by Tomàs Maldonado, seems to refer to some themes introduced by the philosophical debate of the 1920s, in particular the logical neo-positivism of the Vienna Circle, by figures such as Rudolf Carnap, Otto Neurath etc.

[8] As an example, I recall the didactic contribution of Horst W. Rittel, mathematician, physicist and sociologist active in Ulm from 1958 to 1963, who, as documented by the 1958/59 study plan, teaches Methodology (in addition to the Theory of science and operational analysis) in a 70-hour course in the first year (lessons common to all sections). From 196I to 1966, I would like to point out the contribution of Abraham A. Moles, a graduate in philosophy and natural sciences, who, together with Kurd Alsleben, teaches Methodology in two courses, each of 60 hours, for the first and second year (common lessons to all sections). For further details: Lindinger 1988, p. 218.

[9] Bistagnino Enrica, Conversazione sul Disegno a ULM con Giovanni Anceschi [Bistagnino 20 I 8, p. 98].

[10] For further details: Bistagnino Enrica, Teoria e didattica del Disegno [Bistagnino 20 I 8, p. 73- I28.].

[I I] Maldonado Tomàs, Appunti sulliconicità [Maldonado 1974].

[12] Giovanni Anceschi reports: "Aicher pointed out, the Kavalier-Perspektive combined with the accidental point of view, as the preferable formula, insofar as it is easily operable and - so to speak - objective. Moreover, I am convinced that a historical investigation would highlight, even in all the tradition of the modern, the preference for low-grade projective forms and therefore characterized by a high operability coefficient at the expense of their interpretative immediacy, as Abraham Moles would said. Orthogonal projections, axonometry and, at most, the cavaliera perspective: simple and operable projections, chosen also for a certain suspicion towards the manipulative rhetoric implicit in the great perspective" [Bistagnino 20।8, p. II2].

[13] See: Bistagnino 2018, p. II3.

[14] For further details: Bonsiepe 1993, I edition 1975, pp. 169-173.

[15] Bistagnino Enrica, Conversazione sul Disegno a ULM con Giovanni Anceschi [Bistagnino 20 I 8, p. I I 2].

[16] In this regard, the description edited by Gui Bonsiete on the classes of similarity between shapes and on the elementary geometric operations to transform shapes into complex configurations is particularly exhaustive.

The equality or similarity between forms is attributable, according to Gui Bonsiepe to the following classes:

I class: Isometric.

Isomorphs are those elements that have the same shape and the same size.

Example: a tennis ball made up of two equal halves.

II class: Omeometria. Homeomorphs are those elements that have the same shape but different dimensions. Example: an assortment of wrenches for bolts.

III class: Singenometria. Singenomorphs are those elements deformed in an affine or projective way. Example: a parallelogram or an irregular polygon are affine and projective deformations of the rectangle respectively.

IV class: Catametria. Catamorphes are those elements which are neither congruent nor related, but which are linked by a common interfigural relationship. Example: an alphabet, whose letters have very different forms, but which thanks to the similarity of the formal details are received as belonging to a system.

$\checkmark$ class: Eterometria. Heteromorphs are said to be those elements that do not demonstrate an interfigural relationship, but an intrafigural one. Example: a work by Henry Moore or a television set.

$\mathrm{VI}$ class: Ametria. Amorphous are those elements which have neither interfigural nor intrafigural relationships. Ametry is a borderline case between classes of symmetry; it has only theoretical significance in the context of a taxonomy tending towards completeness.

The elementary geometric operations, possibly combined together, to generate linear (on one axis), flat (on two axes), spatial (on three axes) compositional articulations are:

- translation: a simple and linear movement of an elementary part along a translation direction;

- rotation: circular movement of an elementary part around an axis;

- mirror reflection: reversal of the data of an elementary part on an axis or a plane of reflection; 
- expansion: uniform mutation of an elementary part from a predetermined point (center of expansion).

Combined operations:

rotation plus traslation; rotation plus reflection; translation plus reflection; traslation plus dilatation; dilation plus reflection; dilation plus rotation; reflection plus dilatation plus traslation; dilation plus rotation plus reflection; dilation plus rotation plus traslation; turning or reversing (reversal from inside to outside). In Bistagnino 20। 8, pp. 80-83.

\section{References}

Arbel Benjamin (1996). Colonie d'oltremare. In Menniti Ippolito Antonio, Benzoni Gino (a cura di). Storia di Venezia. Dalle origini alla caduta della Serenissima, V, II Rinascimento. Roma: Istituto della Enciclopedia italiana, vol. 5, pp. 947-985.

Arbel Benjamin (20I3). Venice's maritime Empire in the early modern period. In Eric R. Dursteler (a cura di). A Companion to venetian history, 1400-1 797. Leiden: Brill's Companions to European History, pp. I25-254.

Gherado Ortalli, Oliver Jens Schmitt (a cura di). (2009). Balcani Occidentali, Adriatico e Venezia fra XIII e XVIII secolo/ Der Westliche Balkan, Der Adriaraum Und Venedig $13^{\text {th }}-18^{\text {th }}$. Jahrhundert. Venezia-Vienna: Austrian Academy of Sciences.

Hocquet Jean Claude ( 1989 ). Fiscalité et pouvoir colonial.Venise et le sel Dalmate aux XV et XVI siècles. In Balard Michel (ed.) État et colonisation au Moyen Âge. Lyon: La Manufacture, pp. 277-316.

Krekić Bariša (1995). Venezia e l'Adriatico. In Arnaldi Girolamo, Cracco Giorgio, Tenenti Alberto (a cura di). Storia di Venezia. Dalle origini alla caduta della Serenissima, III, La formazione dello stato patrizio. Roma: Istituto della Enciclopedia italiana, vol. 3 , Pp. 5 I-85.

Paladini Filippo Maria (2002). Un caos che spaventa. Poteri, territori e religioni di frontiera nella Dalmazia della tarda età veneta. Venezia: Marsilio Editore.

Praga Giuseppe (198I). Storia di Dalmazia. Milano: Dall'Oglio.

Parrinello Sandro, Picchio Francesca (a cura di). (2019). Dalmazia e Montenegro. Le fortificazioni Venete nel Bacino del Mediterraneo Orientale. Procedure per la conoscenza e la Documentazione Digitale del Patrimonio Storico Fortificato. Pavia: Pavia University Press.

Author

Enrica Bistagnino, Università di Genova, enrica.bistagnino@unige.it

To cite this chapter. Bistagnino Enrica (2020). Connessioni storiche fra il disegno e il design. Qual è la lezione della Scuola di Ulm? Historical connections between drawing and design. What is the lesson of the Ulm School?. In Arena A., Arena M., Brandolino R.G., Colistra D., Ginex G.,
Mediati D., Nucifora S., Raffa P. (a cura di). Connettere. Un disegno per annodare e tessere. Atti del $42^{\circ}$ Convegno Internazionale dei Docenti delle Mediati D., Nucifora S., Raffa P. (a cura di). Connettere. Un disegno per annodare e tessere. Atti del $42^{\circ}$ Convegno Internazionale dei Docenti delle
Discipline della Rappresentazione/Connecting. Drawing for weaving relationships. Proceedings of the 42 th International Conference of Representation Discipline della Rappresentazione/Connecting. Drawing for
Disciplines Teachers. Milano: FrancoAngeli, pp. $103-118$. 